\title{
Cultura dos ofícios patrimônio cultural, história e memória*
}

\author{
Craftwork culture \\ cultural heritage, history and memory
}

\author{
MARIA ELIZA LINHARES BORGES \\ Doutora em Sociologia/IUPERJ \\ PPG-História/UFMG \\ Av. Antônio Carlos, 6627 \\ Belo Horizonte. MG. 31270-901. Brasil \\ mariaeliza.borges@gmail.com
}

\begin{abstract}
RESUMO Este artigo estuda a cultura dos ofícios em uma perspectiva histórica de longa duração. Trabalhamos com a hipótese de que o universo dos ofícios transcende sua dimensão econômica, pois inclui um ethos pautado por regras, saberes, valores, crenças, comportamentos e redes de sociabilidades específicas. Em meio a variações, ambiguidades, tensões e oposições, ela engendrou um mundo social próprio e crucial para o funcionamento longevo das sociedades pré-industriais no Ocidente e no Oriente. Organizado em dois tempos, o artigo destaca, de um lado, as práticas constitutivas da cultura dos ofícios, hoje objeto de interesse de museólogos e de políticas patrimoniais. De outro, analisa os desdobramentos da memória construída em torno da cultura dos ofícios, ao longo do século XIX e primeiras décadas do século XX, período em que ela cede primazia para outra cultura do trabalho: a cultura operária.
\end{abstract}

Palavras-chave patrimônio cultural, memória, cultura dos ofícios

* Artigo recebido em: 12/07/2011. Autor convidado. 
ABSTRACT This article studies craftwork culture in a long term historical perspective. Our hypothesis is that the universe of craftworks transcends the economic dimension, for it involves an ethos based on rules, knowledge, values, beliefs, behaviors and specific social networks. By way of variations, ambiguities, tensions and oppositions this culture created its own world, which proved crucial to the longevity of both Eastern and Western pre-industrial societies. The article focuses on two periods and emphasizes, on the one hand, the constitutive practices of craftwork culture, which today is an object of special interest for those who study museums and elaborate policies linked to historical heritage. On the other hand, it analyses the consequences of the memory of craftwork culture forged during the $19^{\text {th }}$ century and the early decades of the $20^{\text {th }}$ century, a period in which it lost its primacy to another work culture: that of the proletariat.

Key-words cultural heritage, memory, craftwork culture

Sempre a trabalhar

Eterno sofrimento

Sem o prazer de saborear

Um momento de contentamento

(Canção dos padeiros de Troyes, 1690) ${ }^{1}$

\section{Patrimônio Cultural: notas sobre um conceito}

Três questões se destacam no debate contemporâneo sobre o conceito de patrimônio cultural. A primeira nos remete à influência do mundo oriental, sobretudo do Japão, na re-definição dos tipos de bens culturais que integram o patrimônio cultural de um povo; a segunda põe acento em seu impacto na formulação de políticas públicas patrimoniais definidas por órgãos supranacionais, como a UNESCO, por exemplo, e outros nacionais e regionais em diferentes regiões do globo nas últimas quatro décadas; a terceira avalia os limites, desafios e desdobramentos dessas mesmas políticas na construção de representações identitárias - nacionais, regionais e entre grupos sociais -, cujos resultados podem redundar em práticas sócio-culturais mais inclusivas e democráticas. ${ }^{2}$

A partir da década de 1990, principalmente, reflexões oriundas de diferentes matrizes analíticas (nacionais e internacionais) vêm alertando para

1 Trecho da canção dos padeiros, extraído de: La misère des garçons boulangers de la Ville et Faubourgs de Troyes. Troyes: Garnier, 1690. Original: "Toujours travailler. Toujours dans la douler. Sans gouts ni jouir. d'un moment de Bonheur". (Tradução da autora).

2 Sobre este debate, ver: ABREU, Regina e CHAGAS, Mário. (orgs.) Memória e Patrimônio: ensaios contemporâneos. Rio de Janeiro: Lamparina, 2009. 
os limites teórico-metodológicos do uso, quase sempre excludente, do par cultura material/cultura imaterial. Quando no jogo deste par se ilumina o polo cultura material e joga-se na sombra o polo cultura imaterial, o analista restringirá seu olhar, suas indagações, tão somente às propriedades físicoquímicas dos objetos produzidos por uma dada sociedade. Mas será que os materiais, as formas geométricas, as texturas e as cores que compõem um dado objeto nada têm a dizer sobre as relações sócio-culturais que os produziram? ${ }^{3}$ Há muito, Marc Bloch, E. P. Thompson e, mais recentemente, Ulpiano B. de Meneses, Marcelo Rede, dentre outros estudiosos da cultura, lembram que as propriedades físico-químicas de um objeto contêm evidências que, devidamente indagadas, podem narrar histórias exatamente porque falam sobre tradições e experiências de homens e mulheres que criam e reproduzem modos de produzir, circular, difundir e consumir mercadorias. Cabe, pois, insistir: a operação analítica que isola os objetos das condições de sua produção, difusão, circulação, de seu consumo e simbolismo, acaba por concebê-los como coisa. Quando isso ocorre, eles são autonomizados, naturalizados e/ou fetichizados. ${ }^{4}$ Deixam de ser "arte-fatos". Perdem, portanto, seu valor histórico. Mais: impedem que o analista os utilize como fontes de formulação de hipóteses, condição necessária para se compreender a rede de relações sociais e históricocultural que lhe dá sentido.

Em um dossiê dedicado aos Elementos Materiais da Cultura e ao Patrimônio não podemos deixar de registrar: felizmente, hoje é grande o consenso de que a expressão física dos objetos preservados em museus, arquivos e em outros espaços similares não esgota o atual conceito de patrimônio cultural. Este também inclui o saber-fazer, os procedimentos técnicos, os modos de vida, as tradições orais, as línguas, a medicina tradicional, os recursos naturais, assim como as festas, os ritos, as manifestações musicais e cênicas de uma dada sociedade.

Caminhando nesta direção, a UNESCO pautou-se em experiências do Japão/1950, da República da Coreia/1964, das Filipinas/1973 e da Tailândia/1985 e criou a Recomendação de 1993 que propôs o programa

3 MENESES, UIpiano T. Bezerra de. Memória e cultura material: documentos pessoais no espaço público. Estudos Históricos, n.21, v.11, p.91, 1998.

http://bibliotecadigital.fgv.br/ojs/index.php/reh/issue/view/287 (Acesso em 2005).

4 Vale lembrar que já nos anos de 1920/30 Marc Bloch chamava a atenção para a dimensão social e cultural das técnicas: BLOCH, Marc. La tierra y el campesino. Barcelona: Crítica, 2002. Nos anos 70, E. P. Thompson considera a experiência como um fator de mudança da tradição. A nosso ver, este conceito estimula o diálogo entre os polos do par cultura material/cultura imaterial porque nos faz considerar fatores que, a exemplo das migrações de trabalhadores, geram novas vivências com a natureza e a cultura, podendo mudar as formas de se produzir, consumir e significar um mesmo objeto. Sobre o conceito de experiência, ver principalmente: THOMPSON, E.P. Mesa, você existe? In: A miséria da teoria - ou um planetário de erros, uma crítica ao pensamento de Altusser. Rio de Janeiro: Zahar, 1981, p.13-18. Sobre o conceito de cultura material, ver: BUCAILLE, Richard e PESEZ, JeanMarie. Cultura Material. In: Encliclopédia Einaud. Lisboa: Casa da Moeda, 1989, v.16, p.11-47; REDE, Marcelo. História a partir das coisas: tendências recentes nos estudos de cultura material. Anais do Museu Paulista, São Paulo, v.4, p.265-82, jan/dez/1996. http://www.scielo.br/pdf/anaismp/v4n1/a18v4n1.pdf (Acesso em 2010). 
intitulado Sistema de bens culturais vivos ou Tesouros humanos vivos. Assim, a UNESCO não apenas estimulou o mundo ocidental a rever seu conceito de patrimônio cultural, como também legitimou ainda mais os debates e as políticas públicas compromissadas com a valorização e a preservação das manifestações culturais tradicionais e populares.

Uma das primeiras repercussões da referida Recomendação foi o programa do Ministério da Cultura da França, inaugurado em 1994 e intitulado Mestres da Arte. ${ }^{5}$ Aí, o Conselho dos Ofícios de Arte elege mestres que detêm o savoir-faire de ofícios raros e que correm o risco de desaparecer. Como bem explica Regina Abreu, os mestres artesãos escolhidos se comprometem a repassar o segredo de seu métier a um aluno inscrito no programa. Além de valorizar a aprendizagem de habilidades manuais, o programa garante a preservação e a transmissão de saberes ameaçados de esquecimento. Entre 1994-96, 37 mestres foram escolhidos pelo programa; dentre eles, destacam-se os mestres chapeleiro, alfaiate e costureiro de roupas para teatro, impressor de gravuras e estampas, criador e restaurador de vitrais e restaurador de móveis antigos.

Tampouco podemos deixar de lembrar o trabalho realizado no Brasil a partir do Instituto do Registro/Decreto 3.551/2000. Numa linha semelhante ao Tesouros humanos vivos, o IPHAN instituiu o Inventário Nacional de Referências Culturais para viabilizar o registro de ofícios, de seus saberes e modos de fazer, das festas, das manifestações literárias, cênicas, dos rituais, bem como dos lugares que guardam a memória e transmitem tais práticas culturais. Organizada em quatro livros (Livro de registro dos saberes, Livro das celebrações, Livro das formas de expressão e Livro dos lugares), esta modalidade de classificação, organização e valorização do patrimônio cultural nacional "é um instrumento de pesquisa que busca dar conta dos processos de produção desses bens, dos valores neles investidos, de sua transmissão e reprodução, bem como de suas condições materiais de produção". 6

Os debates e as experiências aqui mencionadas têm fortes afinidades com os propósitos deste artigo, cuja atenção recai sobre a Cultura dos Ofícios, prática universal e secular, hoje quase extinta. Fonte de cultura, seus produtos e saberes integram grande parte dos acervos de museus de artes e ofícios, museus de arte popular, museus de cidades e outros similares. São objetos de interesse de políticas patrimoniais, além de integrarem, cada vez mais, o campo de investigação dos historiadores da cultura.

5 ABREU, Regina. "Tesouros humanos vivos" ou quando as pessoas transformam-se em patrimônio cultural - notas sobre a experiência francesa de distinção dos "Mestres da Arte". Outros trabalhos que mencionam a mesma experiência: SANT'ANNA, Márcia. A face imaterial do patrimônio cultural: os novos instrumentos de reconhecimento e valorização; FONSECA, M. Cecília L. Para além da pedra e cal: por uma concepção mais ampla de patrimônio cultural. In: ABREU, Regina e CHAGAS, Mário. (orgs.) Memória e Patrimônio: ensaios contemporâneos, p.34-48; 49-58; 59-79, respectivamente.

6 SANT'ANNA, Márcia. A face imaterial do patrimônio cultural: os novos instrumentos de reconhecimento e valorização, p.55-56. 
Por essas razões, este artigo tem um ponto de partida analítico: o de que a variabilidade e a complexidade da Cultura dos Ofícios são um fenômeno universal relevante e, por isso mesmo, constituem um campo de conhecimento onde a abordagem histórica tem muito a dizer. Aceitando os riscos e o desafio de uma reflexão de longa duração no espaço de apenas um texto, dividimos o artigo em duas partes. Na primeira, partilhamos da tese defendida por Douglas C. Libby - de que o universo dos ofícios transcende sua dimensão econômica e suscita questões de natureza sócio-cultural necessárias à compreensão de uma dada ordem social ${ }^{7}$-, para mostrarmos que a durabilidade e a variabilidade da Cultura dos Ofícios levaram-na a articular dois componentes cruciais do processo histórico: a tradição e a inovação. Na segunda parte do artigo, analisaremos os desdobramentos do uso que diferentes atores sociais fizeram do par memória/esquecimento para pensar a Cultura dos Ofícios entre o século XIX e nas primeiras décadas do século XX, período em que ela perde sua primazia para uma nova cultura do trabalho: a Cultura Operária. Trabalhamos com a hipótese de que esse momento histórico gerou percepções e sentimentos ambíguos em relação à história e ao papel social dos artesãos. Enquanto uns os qualificavam como representantes do tempo do atraso (leia-se, de um mundo feito à mão), portanto integrantes de um passado sem futuro; outros criavam representações profundamente nostálgicas sobre suas trajetórias, contribuindo, assim, para sacralizar a Cultura dos Ofícios. Tal postura, ainda hoje cultuada por muitos, dificulta o exercício de um olhar mais metódico e reflexivo sobre seu legado, sua durabilidade e historicidade.

\section{Variabilidade, tradição e inovação na cultura dos ofícios}

Em 1776 Adam Smith publicava A riqueza das nações. Neste mesmo ano um edito de Luis XVI, proposto por seu ministro Turgot, suprimiu as corporações de ofícios na França. ${ }^{8}$ Sinal do avanço do liberalismo econômico? Certamente. No entanto, os aplausos da fração comercial da nobreza não evitaram a onda de protestos em todo o reino. De um lado, a nobreza rural nele anteviu o estimulo ao êxodo para as cidades e a consequente perda de sua principal fonte de impostos: o trabalho servil. De outro, a rede de corporações de ofícios que então monopolizava grande parte da produção e do comércio do país temeu por seu futuro. Resultado: em 2 de março daquele mesmo ano o rei revogou o edito e demitiu seu ministro. Cinco meses depois um novo edito restabeleceu as corporações de ofícios, porém em novas

7 LIBBY, Douglas C. Habilidades, artífices e ofícios na sociedade escravista do Brasil colonial. In: LIBBY, Douglas C. e FURTADO, Júnia F. (orgs). Trabalho livre, trabalho escravo: Brasil e Europa, séculos XVIII e XIX. São Paulo: Annablume, 2006, p.57-74 (Coleção Olhares).

8 GRANIER, Régis. Les métiers disparus. Bourdeaux: Ed. Sud Ouest, 1999, p.15. 
bases. ${ }^{9}$ Esta sequência de acontecimentos tem sua cota de simbolismo. De um lado, sinaliza as tensões e o jogo de poder que sustentava o Ancien Régime; de outro, mostra que a história nem é voluntarista nem linear. Feita de idas e vindas, ela engendra movimentos que anunciam futuros desejados que só se realizam de forma fragmentada pois são condicionados pelo peso do passado e pelas condições do presente.

Juntamente com as confrarias/irmandades, a instituição corporação de ofícios teve grande amplitude social, política e econômica. Ambas respondiam pela quase totalidade da produção, dos serviços, do comércio e da rede de sociabilidades que conformavam o fazer e os saberes da fração subalterna urbana das sociedades pré-industriais. ${ }^{10} \mathrm{Ou}$ seja, os mestres, artífices (compagnons) e aprendizes; os mestres-juizes; os representantes do poder local, mediadores dos interesses das corporações e os do regime; os comerciantes licenciados para o controle da circulação das mercadorias produzidas no interior dos ateliês. Juntos, eles formavam uma cadeia produtiva reconhecida e chancelada pelo Estado. Ao lado dos camponeses, foram os pilares do Ancien Régime.

Se é certo que os estatutos jurídicos das corporações garantiam proteção econômica a seus membros, também é verdade que as normas das irmandades eram passaportes para os privilégios e a distinção social de seus afiliados. Somados, eles demarcavam as fronteiras que separavam "os de dentro" e "os de fora", isto é, os membros do Ancien Régime contra os estrangeiros, andarilhos e vagabundos. Mais que isso: corporações e confrarias/irmandades foram veículos de controle social, legitimaram a mobilidade social horizontal - em alguns casos, vertical dos artesãos -, a solidariedade e os laços identitários entre seus integrantes.

No longo prazo tais componentes - muitas vezes mais ilusórios que reais - criaram e reproduziram, dentro e fora da Europa, uma parte do que aqui chamamos Cultura dos Ofícios. Isto é, um conjunto de modos artesanais de produzir, pautados por regras, saberes, gestos, valores, crenças, comportamentos e rede de sociabilidades específicas. Em meio a variações, ambiguidades, tensões e oposições, ela engendrou um mundo social próprio e crucial para o funcionamento longevo das sociedades pré-industriais no Ocidente e no Oriente. Assim concebida, a Cultura dos Ofícios não se limitou ao universo das corporações e confrarias/irmandades. Também incluiu os artesãos que atuavam autonomamente dentro e fora das fronteiras dos Impérios Europeus.

9 GOURDEN, Jean-Michel. Gens de métiers \& sans-culottes, les artisants dans la Revolution. Paris: Gréaphis, 1988, p.7, 55.

10 Segundo Le Goff, as confrarias e/ou irmandades foram criadas no século X; a instituição corporação de ofícios foi fruto de um processo mais longo que só se completou, pelo menos na França, com a criação da compagnonnage, no século XVI. LE GOFF, Jacques. Du silence à la parole : une histoire du droit du travail, des années 1830 à nos jours. Rennes: UHB, 2004, p.128. Ver também: DUSANTRA, Pascoal. Compagnonnage: que lire?

http://www.compagnonnage.info/renaissancetraditionnelle/PDF/Compagnonnage.pdf (consultado em 2011). 
Sem pretendermos esgotar o imenso raio de atuação da Cultura dos Ofícios, lembramos os artesãos do Império Otomano. Seu savoir-faire sobre as artes do mosaico, da tecelagem (dos tapetes em especial), das iluminuras, dentre tantas outras, evidenciam a sofisticação técnica, a criatividade e o desenvolvimento de saberes correlatos como o conhecimento de plantas destinadas à tintura dos fios e das telas; o manejo de madeiras adequadas à feitura de teares; o desenho, a pintura e a caligrafia que deram vida e significado às imagens destinadas a celebrar as conquistas e os valores da cultura islâmica. ${ }^{11}$ Variada também foi a participação dos artesãos das diferentes regiões da África transportados ao Novo Mundo pelo comércio de escravos. No âmbito da ordem escravista, artesãos-escravos, livres ou libertos recriaram tradições produtivas de modo a adequar seus saberes às matérias-primas disponíveis na natureza dessa parte do mundo. Quanto mais a historiografia diversifica suas fontes de pesquisa, maiores e mais variadas são as listas de produtos oriundos do saber e do fazer desses artesãos. Machados, foices, enxadas, ferraduras e cravos para cascos de animais, rodas de madeira, teares, fornos de ferreiro, plantas para a cura de animais e pessoas e para o uso culinário, confecção de móveis, panos, cerâmicas, vidro, peças de arte sacra, adornos variados, instrumentos musicais são apenas uma amostra de como o par tradição/ inovação foi manuseado pelos artesãos para suprir as demandas - rural, e sobretudo urbana - do Brasil colonial e imperial. Analisando o caso de Minas Gerais nos anos setecentistas, José Newton C. Meneses sustenta:

Ofícios artesanais e seus oficiais (...), alguns ligados mais diretamente às atividades agrícolas e outros mais urbanos [tinham] ocupações valorizadas porque imprescindíveis à manutenção de uma sociedade urbanizada e diziam respeito à produção comercial de bens básicos, como panos e instrumentos agrícolas e, ainda, ao beneficiamento de produtos primários para a alimentação. ${ }^{12}$

Hoje, o acervo do Museu de Artes e Ofícios de Belo Horizonte (MAO), que se define como "um lugar de encontro do trabalhador consigo mesmo", contém uma parcela importante da produção brasileira de artesãos dos séculos XVIII, XIX e XX.13 Ao percorrê-lo o visitante se depara com os ofícios de rua, da fundição, do entalhe, da conservação e transformação dos alimentos, do fio e do tecido, dentre tantos outros. Ao longo da "viagem"

11 PAMUK, Orhan. Meu nome é vermelho. São Paulo: Companhia das Letras, 2004. O autor relata com detalhes o funcionamento dos ateliês reais encarregados de produzirem as narrativas visuais do cotidiano e das conquistas dos sultões. Nesse romance de muitas tramas, é possível perceber o peso da tradição tanto na formação dos aprendizes quanto no uso de tintas e na concepção das imagens produzidas nos ateliês reais.

12 MENESES, José Newton C. O Continente Rústico: abastecimento alimentar nas Minas setecentistas. Diamantina: Maria Fumaça, 2000, p.229; do mesmo autor, ver: Homens que não mineram: oficiais mecânicos nas Minas Gerais Setecentistas. In: RESENDE, M. Efigênia L. de e VILLALTA, Luis Carlos. História de Minas Gerais: as Minas Setecentistas. Belo Horizonte: Autêntica, 2007, v.1, p.377-402.

13 Uma visita virtual a este museu pode ser feita através do site www.mao.org.br. 
proposta pelo museu, vitrines, mapas, manequins, recursos multimídias, litografias e fotografias compõem os cenários destinados a estimular a curiosidade e o interesse dos visitantes. Como se verá mais adiante, neste e em outros museus do gênero, as imagens - usadas mais como ilustração - aguardam ser tratadas como artefatos, como parte da Cultura dos Ofícios, que também o são.

Mas afinal, que cultura própria foi esta que abarcou homens e mulheres de tantas regiões do globo em um período histórico tão amplo? Que atributos e regularidades permitem nomeá-la: Cultura dos Ofícios?

Até o momento identificamos três categorias de organização e atuação de seus membros, dentro e fora de uma mesma sociedade. As corporações de ofícios e as confrarias/irmandades responderam pela dimensão institucional da Cultura dos Ofícios, estruturada entre os séculos X e XVIII no mundo ocidental. Seus estatutos variaram no interior de uma mesma categoria de artesãos, tanto nas áreas metropolitanas quanto nas coloniais. ${ }^{14}$ As regras que regulavam seu ethos foram seu traço comum.

A segunda categoria se aproximava das corporações. Mas, por ser diretamente subordinada ao Estado, ela detinha especificidades, como a importação de mestres de ofício e matérias-primas. Além disso, seus artesãos produziam artigos para exportação e ligados à manutenção da máquina estatal, tais como cunhagem de moedas, armamentos, embarcações para o comércio transatlântico etc. ${ }^{15} \mathrm{Em}$ que pesem tais particularidades, essa categoria de ofícios também manteve o mesmo ethos das corporações.

A terceira categoria era a mais variada e numerosa, referia-se aos artesãos autônomos. Incluía ofícios desprestigiados, como os domadores de cavalos franceses no século XVl; ofícios novos, surgidos à medida que as sociedades se urbanizavam, sofisticavam suas demandas e requeriam mais especializações. A título de exemplo citamos o caso dos arquitetos cujo saber rivalizava com o dos carpinteiros. Há ainda os ofícios que ao longo do tempo saíram da categoria artes mecânicas para integrar o universo das artes liberais: escultores, pintores, organistas. Outra variação sua incluía artesãos antes pertencentes às corporações e que passaram a atuar por conta própria, como ocorreu com os barbeiros do Rio de Janeiro do final do século XVIII. Assim como no Brasil, na França e provavelmente em outras regiões europeias, a categoria autônomo também englobava os trabalhadores de

14 BOSCHI, Caio C. Irmandades, religiosidade e sociabilidades. In: RESENDE, M. Efigênia Lage de e VILLLALTA, Luis Carlos. (orgs.) História de Minas Gerais: as Minas setecentistas, v.2, p.77-108.

15 Sobre essas questões, ver: TACHOT, Louise Bénat. La navegación hispánica en el Atlántico: aspectos laborales y técnicos (siglos XVI-XVII). In: PAIVA, Eduardo F. e ANASTASIA, Carla J. (orgs.) O trabalho mestiço: maneiras de pensar e formas de viver, séculos XVI a XIX. São Paulo: Annablume, 2002, p.79-104; Já no século XVIII, Colbert introduziu mudanças no sistema corporativo francês ligado à tecelagem. A produção de gobelins e de outros artigos de luxo, destinados à exportação, tornaram-se monopólio estatal. Sobre isso ver: DADOY, Mireille. La notion de métier: um operateur dans la formation et le marche du travaille. Educação \& tecnologia. Belo Horizonte: CEFET, n.3, v.13, p.40, set/dez 2008 
áreas rurais que dominavam vários ofícios e cobriam, prioritariamente, as demandas das propriedades rurais. Nos períodos de entressafra eles atuavam como mão-de-obra avulsa nas cidades. ${ }^{16}$ No Brasil, especificamente, temos os indígenas, ligados ou não às missões, homens livres pobres, os libertos e os escravos. Uma parcela destes funcionava como mão-de-obra alugada. ${ }^{17}$ Por fim, há que mencionar a grande quantidade de escravos e libertos chamados de "negros de ganho", uma modalidade típica das áreas urbanas de sociedades escravistas no século XIX, muito ligada à prestação de serviços. ${ }^{18}$ Embora autônomos, os materiais usados e os critérios técnicos para a produção de seus artigos eram pautados pelo ethos das corporações.

Ora, a grande variabilidade de ofícios e de suas formas de atuação não seriam evidências da inviabilidade do uso do conceito de Cultura dos Ofícios? Antes de descartamos tal possibilidade, vale considerar: conceitos são recursos analíticos que selecionam e articulam traços da realidade de modo a representar a complexidade de suas relações. Antes: são condições para a ruptura epistemológica. Sem ela, o analista se restringe às visões próprias do senso comum, permanecendo, assim, no nível das aparências. Mas não é a ciência um modo de conhecer comprometido com a busca de relações, nem sempre aparentes, necessárias à compreensão das motivações e das racionalidades dos atores sociais? Como tipos ideais os conceitos priorizam as regularidades dos fenômenos sociais. Conhecendo-as, pode-se avaliar o grau de estabilidade de uma dada sociedade ou mesmo mensurar o tempo de formação e duração de uma cultura. Contudo, é bom lembrar E. P. Thompson quando nos ensina que "a história tem um tipo diferente de lógica, adequado aos fenômenos que estão sempre em movimento, que evidenciam - mesmo num único momento - manifestações contraditórias, [por tudo isso, pode-se dizer que] a história não conhece verbos regulares". ${ }^{19}$

Esta breve reflexão sugere considerar o conceito de Cultura dos Ofícios tanto por seus atributos recorrentes, quanto por aqueles que quebram suas regularidades. Dentre os atributos que dão identidade à Cultura dos Ofícios destaca-se seu ethos. Fundada numa rígida hierarquia social, constituída por mestres, artífices e aprendizes, ela pressupunha um longo aprendizado (que podia variar de 2 a 10 anos, dependendo do ofício) de saberes que requeria habilidades específicas, inclusive com a domesticação do corpo para lidar com os instrumentos de trabalho. Estes saberes eram segredos (mistérios) transmitidos oralmente e na prática cotidiana, de geração em geração. As atividades dos ateliês eram coletivas; a confecção dos artigos

16 CHOLEAU, Jean. Métiers, confraries et corporations de Vitré avant la Revolution. Vitré: Imprimerie Chatelaudren, s/d, t.1, p.11-12.

17 Sobre o trabalho indígena no Brasil, ver: LIMA, Carlos A. M. Artífices do Rio de Janeiro, 1790-1808. Rio de Janeiro: Apicuri, 2008, p.238-241; sobre o aluguel de escravos: LIBBY, Douglas C. Trabalho escravo e capital estrangeiro no Brasil: o caso do Morro Velho. Belo Horizonte: Itatiaia, 1984, ver principalmente as p.96-105.

18 SILVA, Marilene Rosa Nogueira da. Negros ao ganho: a nova face da escravidão. São Paulo: Hucitec, 1988

19 THOMPSON, E. P. A lógica da historia. 1981, p.48, 57. 
de uso era pautada por sua qualidade técnica e sua durabilidade. Nas sociedades ocidentais, o tempo de trabalho era regulado pelo calendário cristão; nas demais, seguia os calendários das crenças locais. Em alguns casos, os ciclos da natureza também propunham calendários produtivos para os ateliês urbanos que dependiam da mão-de-obra rural e, portanto, não funcionavam no período de plantio e colheita. Os aprendizes, e em alguns casos os artífices, viviam na casa de seus mestres; partilhavam sua mesa e seus hábitos de vida. Não raro, artífices se uniam em matrimônio com filhas de mestres ou mesmo com suas viúvas, garantindo, assim, sua mobilidade horizontal antes de completarem os tempos institucionais de ascensão sócio-profissional. Vale lembrar: a mobilidade de aprendiz para artífice dependia da palavra do mestre, mas a passagem de artífice para mestre era definida externamente; só ocorria após sua aprovação no exame feito por um mestre-juiz e chancelado pelo poder público local.

O ethos da Cultura dos Ofícios também rezava que o trabalho no ateliê fosse diurno e feito sob encomenda, não havia, portanto, excedente de produção. Com as portas sempre abertas para o espaço público, os mestres se expunham à vigilância alheia, controlavam o tempo de produção de cada objeto, mantinham a disciplina e garantiam, com rigor, às vezes com excessos, o aprendizado e a obediência de seus subalternos. Esse padrão produtivo orientava o funcionamento do mercado fazendo com que os artesãos autônomos também primassem pela qualidade e pela durabilidade dos objetos produzidos, assim como pela preservação do segredo que a feitura de seus objetos demandava.

Os segredos dos ofícios iniciavam-se com a compra de matéria-prima, atividade que pressupunha viagens às vezes por regiões distantes. As trocas daí advindas criavam e mantinham redes comerciais imprescindíveis ao sucesso dos ateliês. Modos tradicionais de produzir iam, muitas vezes, sendo alterados em função da utilização de novos materiais. As inovações técnicas, daí advindas, geravam novos produtos, re-criavam os saberes tradicionais. Em torno das viagens, o convívio entre pares selava e ampliava seu capital social; nutria cumplicidades e reproduzia os valores da Cultura dos Ofícios que se dizia pautar na confiança mútua, na solidariedade interpares e no mistério em torno de seus modos de fazer.

Para publicizar e glorificar seu ethos, as corporações e as confrarias/ irmandade elegiam seus santos padroeiros, criavam bandeiras, insígnias, canções, poemas e representações visuais. Nas ocasiões festivas, civis e religiosas, essa gramática - composta por símbolos textuais, visuais e por rituais - conferia visibilidade a seus membros, projetando-os na cena pública, assegurando-lhes distinção social, reafirmando sua identidade frente "aos de fora" e sua inter-dependência para com o poder público e a lgreja.

Hoje, esse modo de viver vem sendo desnudado por pesquisas históricas. Nelas, a Cultura dos Ofícios se nos apresenta como um fenômeno 
em movimento, portanto, pautado por tradições e inovações técnicas que a seu turno engendram distintas motivações, diferentes práticas, ambas marcadas por tensões e conflitos também diversos. Quanto mais as análises históricas descortinam o imaginário de "nobreza e pureza" que envolveu essa cultura, mais sua trajetória histórica ganha realidade; dá a ver suas variações internas; é, enfim, historicizada.

Os casos da França e do Brasil, mais enfatizados neste artigo, apresentam diferentes tipos de "desvios" no cotidiano corporativo dos artesãos dos séculos XVIII e XIX. As cidades protoindustriais francesas são as que apresentam mais evidências de tensões nesse sistema produtivo e em suas relações sociais. Em Lyon, por exemplo, cerca de 25\% da população estava envolvida com a manufatura da seda. Em meados do século XVIII ela empregava 35.000 trabalhadores; destes, 350 eram fabricantescomerciantes; 6.000 mestres de ateliês empregavam 4.000 mulheres e 5.000 crianças (ambas oriundas de famílias de artífices e aprendizes). Situação semelhante se repetia nas áreas têxteis de Troyes, Lille, Amiens e Nives e também em Saint-Etienne onde o Estado mantinha uma base de produção de armamentos. Uma parcela significativa da mão-de-obra das cidades têxteis era originária das áreas rurais que, migrando para essas áreas urbanas, definitivamente ou nos períodos de entressafra, engrossava a categoria artesãos autônomos. ${ }^{20}$ Também podemos supor que, sendo polos comerciais importantes, as regiões protoindustriais incorporassem mão-de-obra estrangeira em princípio interditada pelas corporações e confrarias/irmandades.

Dissemos anteriormente que trabalho diurno era uma das tradições da Cultura dos Ofícios. Porém, na prática o tempo de trabalho podia chegar a dezoito horas por dia, indo das cinco horas da madrugada às vinte horas. O fato dos aprendizes e de muitos artífices morarem nos ateliês, que também eram a casa de seus mestres, contribuía para se burlar esta e outras normas do ofício. A documentação de época também se refere à umidade, à ausência de ventilação e à falta de higiene nos ateliês. Razão de ser de doenças reumáticas, febre tifoide e outras enfermidades que acometiam les gens de métiers. Os maus tratos dos mestres eram uma fonte da evasão de aprendizes e artífices que se tornavam mão-de-obra rotativa quando não engrossavam o universo dos chamados vagabundos. Objeto da vigilância policial desde o século XVII, os artífices (les compagnons) eram considerados gente perigosa. Em Paris, dos 823 casos de polícia registrados entre 1730 e1768, 550 eram relativos a problemas no universo das Artes e Ofícios; destes, cerca de $60 \%$ dizia respeito a brigas de rua, furto e vagabundagem dos compagnons, os outros $40 \%$ se referiam a queixas de mestres contra

20 GOURDEN, Jean-Michel. Gens de métiers \& sans-culottes, p.18-21, 59-71. 
o comportamento independente e anárquico de seus subalternos. ${ }^{21}$ Não por acaso, William Sewell destaca a presença de aprendizes e artífices nas fileiras dos sans-culottes tanto na movimentação que levou à queda da Bastilha, quanto na tomada do Fauborg Saint-Antoine em 1795, aí defendendo uma república una e indivisível, garantida pela vigilância popular. ${ }^{22}$

O trecho da canção que abre este artigo, e o que se segue, são representações das tensões vivenciadas entre mestres e aprendizes na França dos anos setecentos. Os padeiros, citados na primeira canção, eram ligados a uma corporação de ofícios; os sapateiros, mencionados abaixo, eram trabalhadores autônomos.

Sapateiros são piores que bispos

As segundas, vão festejar

Na terça, vão à taberna brindar

Na quarta, têm mal estar

E na quinta, vão ao bar

Na sexta, pegam no batente

Pois no sábado, tem trabalho pela frente

No domingo, vão falar com seu mestre:

Queremos dinheiro! As botas? Não fizemos um par.

- Não Ihe darei! Somente se as botas me entregar!

- Sem dinheiro, outro mestre vou procurar!23

O cotidiano das esposas, filhas e viúvas dos mestres tampouco era fácil. Além de se ocuparem das tarefas da casa - que incluía a família expandida: filhos, maridos, aprendizes e artífices -, elas ajudavam nas atividades do ateliê. Tinham, portanto, dupla jornada. A mão-de-obra feminina também esteve presente no trabalho das manufaturas das cidades protoindustriais, como mostrado anteriormente, e nos ofícios ligados à produção de joias e bijouterias, ao polimento de metais, móveis e instrumentos musicais e nos orfanatos infantis e de idosos. Na Paris setecentista, as mulheres representaram $60 \%$ da população ativa.

Nesse mesmo período, burlar as normas das corporações e/ou confrarias/ irmandades tornou-se prática comum. Segundo Jean-Michel Gourden, maittres d'ateliers da capital francesa assim procediam seja para usarem mão-deobra não qualificada, isto é, não formada nos ateliês, seja para acumularem funções de fabricante e comerciante. Após o edito de Luis XVI, de agosto de

21 Sobre o cotidiano dos ateliês ver: GOURDEN, Gens de métiers \& sans-culottes, p.55-96; ver também: MONTEIL, Alexis. Histoire de l'industrie française e de gens de métiers. Paris: Bibliothèque Nouvelle, t.2, 1872.

22 SEWELL, William. Lavoro e rivoluzione in Francia. II linguaggio operaio dall' ancient régime al 1848. Bologna: ॥ Mulino, 1987.

23 Trecho da canção dos sapateiros, extraído de: GRIGAUT, M. Histoire du travail et des travailleurs, Paris: Delagrave, 1931. Original: "Les cordonniers sont pires que d'eveques. Tous les lundis, ils en font une fete. Et le mardi, ils vont boire la chopinette, Le mercredi, ils ont mal à la tete, Et le jeudi, vont voir leur fillettes, Le vendredi, ils commencent la semaine, Et le samedi, les bottes ne sont pas faites, La dimanche, ils vont trouver leur maitre: Leur faut l'argent, les bottes ne sont pas faites. -Tu n'en auras pas, si les bottes ne sont pas faites! - Si je n'ai pas,je veux changer de maitre!" (tradução da autora). 
1776, muitos ofícios foram reunidos em uma só corporação. Ao todo a França passou a ter 44 tipos de corporações ${ }^{24}$ Tudo indica que esta lei formalizou uma tendência já manifesta em diferentes regiões do reino. Embora não tenhamos o número de corporações anteriores, Mireille Dadoy informa que o Livre des métiers, referente às corporações do século XIII, reeditado em 1837 e 1879, menciona 100 ofícios para o período. No século XVIII, enquanto muitas especialidades já tinham desaparecido, as demandas da sociedade que ia se urbanizando e diversificando provavelmente impulsionaram o surgimento de outras. Vale ressaltar: o referido livro foi fruto de uma determinação do poder público para melhor controlar e arbitrar os constantes conflitos intra e entre corporações. ${ }^{25}$ Dele constavam as normas que regulavam as relações de trabalho no interior dos ateliês, os exames de mestres, o comércio de mercadorias, os impostos e as relações das corporações com o poder local. Livros como este eram parâmetros para as relações corporativas que variavam segundo o tipo de trabalho ou serviço ofertado inclusive em uma mesma localidade. Deles estavam ausentes os segredos (mistérios) do saber de cada ofício, transmitidos, como dito anteriormente, via tradição oral, na prática cotidiana.

A tendência, cada vez maior, à liberalização do mercado parece não ter alterado a qualidade de vida da maioria de aprendizes e artífices, cujo trabalho, desde a Idade Média, apenas garantia-Ihes a subsistência. O inventário pos-morten de um compagnon do século XVIII - que não morava na casa de seu mestre de ateliê - atesta que ele possuía uma cama, uma mesa de madeira branca, 4 cadeiras, 5 colheres, 8 garfos de estanho, 6 garrafas de vidro e 2 pratos. ${ }^{26}$ Terá sido esta a situação da maioria dos membros da Cultura dos Ofícios na França dos setecentos?

Os dados de que dispomos indicam que foi das corporações de ofícios, assim como das confrarias/irmandades, que nasceu a pequena burguesia, sobretudo sua fração ligada ao comércio interno. Contudo, os casos de artífices que alçavam à condição de mestre e/ou chegavam a acumular a função de comerciante parecem ter sido raros. Segundo Mireille Dadoy, "os membros das corporações e das confrarias/irmandades representavam uma porção mínima da população do reino no século XVIII". ${ }^{27}$ Além de não esclarecer o que significou, quantitativamente, essa "porção mínima da população do reino", a autora só está considerando a população ativa pertencente às corporações de ofícios e à confrarias/irmandades. Ora, são inúmeros os estudos que chamam a atenção para o trabalho de artesãos autônomos. Além disso, observa Jean-Marie Gourden que os censos franceses setecentistas

24 GOURDEN, Jean-Michel. Le peuple des Ateliers: les artisants du XIXe siècle. Paris: Ed Creaphis, 1992, p.28/29.

25 DADOY, Mireille. La notion de metiér: un operateur dan la formation et le marche du travail. Educação \& tecnologia Belo Horizonte, v.13, n.3, 2008, p.40. A supressão da instituição corporação de ofícios ocorreu em 04/09/1791 com a aprovação da lei Le Chapelier.

26 SEE, H. Histoire economique de France. Paris: Armand Colin 1939, t.1, p.381.

27 DADOY, Mireille. La notion de metiér: un operateur dan la formation et le marche du travail, p.40. 
careciam de precisão. Classificavam como "sem métier" todo e qualquer indivíduo que não fosse servo ou não pertencesse a uma confraria ou a uma corporação. Mesmo levando em conta que $80 \%$ dos 20 milhões de habitantes da França do século XVIII viviam ou dependiam do mundo rural e de que as práticas corporativas eram atividades majoritariamente urbanas, a historiografia sobre o trabalho artesão é farta em evidências que comprovam tanto o uso do trabalho rural sazonal nos ateliês, quanto a existência de diferentes modalidades do trabalho artesão autônomo. Como observado anteriormente, muitos dos que compuseram as fileiras dos sans-culottes eram artesãos. Não seria, pois, incorreto afirmar que "massa de trabalhadores urbanos" na França do século XVIII foi maior do que quer Mireille Dadoy.

Na bibliografia por nós consultada para o caso do Brasil também nos deparamos com inúmeros casos de "desvios" das normas corporativas. A análise de Douglas C. Libby - baseada em diversos estudos de casos de diferentes regiões da colônia, inclusive de Portugal - atesta a coexistência, no território colonial, de distintas origens étnicas dos mestres e aprendizes e diferentes laços das "estruturas agremiadoras formais" com poder público local; a "inexistência de estrutura corporativa formal"; a "confluência de identidades entre os ofícios e as várias irmandades". ${ }^{28} \mathrm{~A}$ tese mais corrente sobre a variabilidade da Cultura dos Ofícios no Brasil (com a qual concordamos), chama atenção para o papel que a instituição escravidão teve tanto na introdução de novas formas de organização do trabalho artesão, quanto no emprego de novas técnicas e novos saberes para a produção dos objetos.

Contudo, tendemos a discordar de parte da hipótese aventada por alguns estudiosos que defendem a hipótese de que o trabalho artesão no Brasil escravista difere por completo daquele que orientou a Cultura dos Ofícios na Europa. Ancorado em uma massa de dados extraída cartas de exames de artífices, de inventários pos-morten, documentação de irmandades, corporações e das câmaras municipais, além de uma vasta pesquisa bibliográfica, Carlos A. M. Lima, por exemplo, sustenta que "o impacto da escravidão e o domínio exercido pelo capital mercantil reformularam de alto a baixo as práticas do artesanato corporativo de origem européia". ${ }^{29}$ Ora, como vimos mostrando, uma parcela significativa da historiografia francesa atesta o expressivo descumprimento das normas institucionais de suas corporações de ofícios ao mesmo tempo em que atesta a tendência crescente da autonomização do trabalho artesão. Analisando por este ângulo, consideramos que a hipótese de Lima - muitíssimo bem fundamentada no que se refere aos "desvios" do modelo corporativo europeu" - é correta

28 LIBBY, Douglas C. Habilidades, artífices e ofícios na sociedade escravista do Brasil colonial, p.57-74. Além dos trabalhos referenciados em sua bibliografia, ver; MARTINS, Monica de Souza N. Entre a cruz e o capital - as corporações de ofícios no Rio de Janeiro após a chegada da Família Real (1808-1824). Rio de Janeiro: Garamond, 2008, especificamente p.91.

29 LIMA, Carlos A. M. Artífices do Rio de Janeiro, 1790-1808, p.41. 
no que tange a dois aspectos: o uso de mão-de-obra escrava e liberta e a influência dos saberes dos artesãos de origem africana nos modos de produzir no território americano do Império Português. Mas, será que sua afirmação não estaria desconsiderando que "as práticas do artesanato corporativo de origem europeia" também foram marcadas pela variabilidade no tempo e no espaço? Ao fazê-lo, será que o autor não estaria concebendo a Cultura dos Ofícios da Europa como um fenômeno carente de dinamismo, portanto, fossilizado? Como explicar a participação de aprendizes e artífices nas fileiras dos sans-culottes? Será que a variabilidade, cada vez maior, das e nas práticas de trabalho, dos e nos comportamentos dos diferentes segmentos corporativos não estaria indicando adequações de suas motivações e de seus propósitos aos ventos que anunciavam o advento do liberalismo? Como explicar o fato de que mestres e comerciantes que lucravam com o sistema corporativo lutaram pela manutenção de seu modo de produzir e viver? Por que aprendizes e artífices teriam engrossado as fileiras dos sans-culottes na movimentação contra o Ancien Régime, ao invés de permanecerem ao lado de seus mestres e dos comerciantes que defenderam reformas, mas não a derrocada do regime?

As questões que aqui pontuamos visam tão somente estimular a continuidade das boas reflexões, oriundas da produção acadêmica contemporânea, sobre o trabalho dos artesãos das e nas sociedades pré-industriais. Acreditamos que a proliferação de estudos de casos certamente contribuirá não apenas para uma melhor caracterização da variabilidade desse modo de produzir e viver, como também para o refinamento do conceito de Cultura dos Ofícios que aqui tentamos caracterizar.

\section{Modos de lembrar e esquecer a Cultura dos Ofícios}

A moldura desta litografia (Figura 1) abre-nos dezesseis pequenas janelas com representações de artífices, dos sexos feminino e masculino, em seus ambientes de trabalho. ${ }^{30}$ Sua edição encontra-se em um livro que se aproxima do modelo dos almanaques tão comuns na época. Embora ele apresente o ano de 1850 como data de sua edição, provavelmente foi publicado após 1900 porque dentre as outras onze imagens nele contidas encontra-se uma do pavilhão do trabalho da Exposição Universal de Paris deste mesmo ano. Suas 126 páginas de textos informativos sobre ofícios, como impressor e gravador de imagens, livreiros, padeiros, comerciantes de vinho e de tecidos, dentre outros, também apresentam narram a história de alguns ofícios que, segundo os autores, já eram mencionados na Bíblia.

30 DEMBOUR \& GANCEL. Le jeune industriel Alphabet complet des Arts et Métiers: contenant des connaissances utiles. Metz: Litographie Dembour e Gangel, 1850.p.32. Imagem cedida pela BnF. 


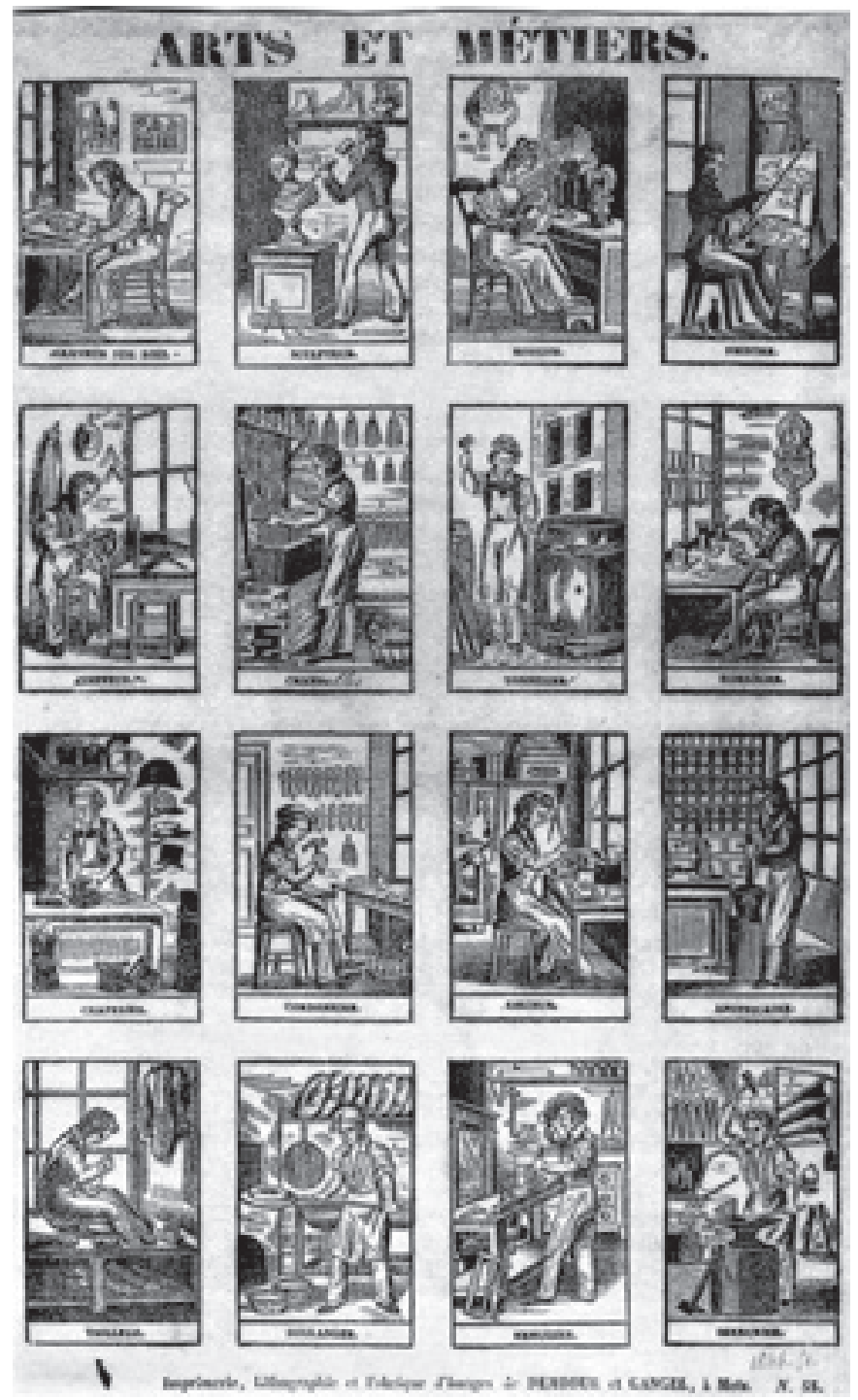

\section{Figura 1}

Fonte: DEMBOUR \& GANCEL. Le jeune industriel: Alphabet complet des Arts et Métiers - contenant des connaissances utiles. Metz: Litographie Dembour e Gangel, 1850.p.32. Imagem cedida pela $\mathrm{BnF}$.

Como o livro não faz qualquer alusão a tipos distintos de divisão social do trabalho, sua leitura sugere a apreensão de uma história do trabalho movida apenas por mudanças técnicas. Para reforçar esta visão, um texto, sucinto e afirmativo, enfatiza as "prodigiosas" transformações do mundo do trabalho cada vez mais visíveis e velozes com o desenvolvimento da química, grande impulsionadora das técnicas para se tingir tecidos e madeiras, além de responsável pelo uso do reino vegetal, fonte de produtos de utilidade para a indústria. Na sequência, o texto aplaude a cooperação entre diferentes ofícios de um mesmo ramo, narra a história da máquina a vapor e da litografia. Disseminados no livro, os elogios à revolução industrial desembocam na 
reprodução de da imagem do pavilhão do trabalho da Exposição Universal de Paris de 1900. Esta menção não é aleatória. Afinal, este evento vem sendo considerado por muitos estudiosos como a Exposição Universal que mais investiu na montagem de cenários destinados a celebrar o trabalho nas indústrias e as inovações técnico-científicas. Por fim, Dembour e Gancel finalizam seu trabalho de edição com uma "oração" infantil que reforça o valor da obediência, honestidade, solidariedade, caridade e higiene.

O manejo das gramáticas textual e visual do livro tem endereço e propósito definidos: dirige-se ao público que, desde o século XIX, consome publicações que mesclam vulgarização científica e almanaques. Neles, a historia é, em geral, apresentada como vocacionada ao progresso técnicocientífico e ao triunfo da indústria. As formas tradicionais de produzir e viver são vistas como ultrapassadas, porque próprias de um tempo pretérito, fadado ao desaparecimento.

No entanto, uma análise mais detalhada do conjunto do livro não apenas nega a pretendida linearidade da história, como também mostra o difícil e tortuoso processo de construção da linguagem que define o modo de produção industrial. O título do livro - O jovem industrial, alfabeto completo das artes e ofícios -, aliado à litografia aqui apresentada, é indício de que ainda no início do século XX as relações de trabalho combinam distintos tempos sociais. Não por acaso, Jean-Michel Gourden e William Seweell sustentam que até 1848 a imprensa operária francesa não dispunha de uma linguagem própria. Termos como artesão, atelier, tailleur, provenientes da Cultura dos Ofícios, eram largamente empregados nas manchetes e no corpo das matérias produzidas pela nascente imprensa operária. ${ }^{31}$ No século XIX, as expressões indústria e industrial tanto se referiam ao mundo da fábrica, quanto ao trabalho do pequeno produtor que operava segundo padrões da produção artesanal. O estudo de Seweell, assim como de analistas canadenses, como será mostrado mais adiante, atesta que este fenômeno não foi uma especificidade francesa; ao invés, também esteve presente na Inglaterra, na Alemanha, nos Estados Unidos, no Canadá e muito provavelmente em outras sociedades. ${ }^{32}$ Segundo Gourden até 1860, o trabalho feito em ateliês franceses representava $60 \%$ da produção industrial. Até as vésperas da Primeira Grande Guerra o interior do país, ainda muito rural, dependia do trabalho artesão, exceto na indústria têxtil e na produção siderúrgica. ${ }^{33}$ Cabe ressaltar, no entanto, que essa coexistência era tensa, porque permeada por valores muitas vezes conflitantes. O estudo de Jean-Pierre Hardey e David-Theiry Ruddel sobre a história do

31 Sobre esses dados, ver: GOURDEN, Jean-Michel. Le peuple des Ateliers, 1992, e SEWELL, William. Lavoro e rivoluzione in Francia.

32 SEWEEL, William. Lavoro e rivoluzione in Francia. II linguaggio operaio dall' ancient régime al 1848, p.9-37.

33 GOURDEN, Jean-Michel. Gens de métiers \& sans-culottes, p.134 e Le peuple des Ateliers, p.56-57. 
sindicalismo canadense destaca a convivência conflitante entre valores das duas culturas do trabalho no meio operário de Quebec. Conforme relatam, em 1814 artesãos que trabalhavam em uma indústria de ferro aderiram a uma greve por salários condizentes com sua qualificação, mas se recusaram a apoiar outra greve que lutava pela redução da jornada de trabalho de dezoito horas para dez horas. Este dado mostra que quando o protesto valorizava as habilidades, os saberes, os segredos dos mestres, o movimento contava com seu apoio e participação. Porém, quando a reivindicação destinava-se a perpetuar as relações de trabalho industrial, mesmo que de forma menos draconiana, os antigos oficiais de ateliê não reconheciam sua legitimidade e se recusaram a apoiá-la. Temos ai uma demonstração da tensa convivência entre valores e ideais de orgulho, próprio da Cultura dos Ofícios, com os ideais democráticos de justiça e igualdade, nascidos com o mundo inaugurado pela Revolução Francesa. ${ }^{34}$

Outra evidência da ausência de uma terminologia tipicamente operária, dentro e fora da Europa ao longo do século XIX e nas primeiras décadas do século XX, está nos nomes de museus, conservatórios e escolas dedicadas à formação de mão-de-obra para a indústria. Todos eles usavam a expressão artes e ofícios em suas designações. Criado em 1799, o Conservatoire des Arts et Métiers foi uma instituição que reunia engenheiros e estava interessado nas novas conquistas da ciência e da tecnologia. Mantinha cursos de química, mecânica, hidráulica e direitos de patentes, destinados à formação de técnicos e novos inventores. Seu exemplo foi seguido em diferentes lugares. Em dezembro de 1826, o rei Guillaume I da Bélgica inspirou-se no modelo francês e criou "seu" Conservatoire des Arts et Métiers, também dedicado às inovações trazidas pela ciência. Um documento da instituição, datado de 1827, deixa claro seu propósito: "ser um complemento de uma escola industrial", onde os alunos adquiririam conhecimentos teóricos e práticos necessários à sua capacitação para o trabalho das novas indústrias do país. ${ }^{35}$ Data desse mesmo período a iniciativa, malograda, do ministro Guizot, de criar Écoles des arts e métiers destinadas a formar mão-de-obra para a indústria francesa, sobretudo no campo da fundição. O capítulo, Le monde de l'atelier entre mutations et continuités, de um dos livros de Jean-Pierre Guinot, mostra que somente após 1870 a expressão école technique iria substituir os termos écoles d'apprentis e écoles manuelles d'apprentissage usados para definir os campos do ensino profissional para formação de mão-de-obra industrial. ${ }^{36}$

34 HARDEY, J-P. e RUDDEL,D.T. Les apprentis artisans à Quebec, 1660-1815. Montreal: Presses de L'Université de Quebec, 1977, p.37-58.

35 CLAES, Marie-Christine. Marcelin Jobard et le musée de l'industrie de Bruxelles. La revue: musée des arts et métiers-Innovations, collections, musées. Paris: CNAM, n.51/52, p.44-55, fev/2010.

36 GUINOT, Jean-Pierre. Formation professionnelle et travailleurs qualifies depuis 1789. Paris: Domat-Mont chrestiaen, 1946, p.140-149. 
Ora, se a linguagem nomeia o mundo e suas relações sócio-culturais, esses exemplos atestam, de um lado, o tortuoso processo de hegemonia da Cultura Operária e, de outro, a importância da Cultura dos Ofícios pelo menos até o início do século XX. Da mesma forma que a gramática textual, a memória oral de muitos trabalhadores da primeira metade do século XX também sinaliza que a Cultura dos Ofícios não foi eliminada, de imediato - como querem alguns estudiosos do mundo do trabalho -, pela Cultura Operária. Será que o mesmo ocorreu com a cultura visual do período?

Voltemos à litografia que inicia esta seção do artigo. Representados de frente ou de perfil, apenas o tanoeiro trabalha na rua; os demais desempenham seus ofícios em espaços fechados, simulando os ateliês que mantinham suas portas de entrada abertas ao público, como rezava uma das normas de trabalho das corporações de ofícios. Os instrumentos de trabalho e as vestimentas particularizam os ofícios; o arranjo ordeiro dos ateliês e a performance compenetrada de cada oficial sugerem ambientes limpos, higienizados, portanto muito distintos do que na realidade foram esses espaços de produção no período pré-industrial. A ausência de aprendizes e artífices é outro sintoma de como a cultura visual de fins do século XIX e início do século XX ia recriando a memória do viver artesão, responsável por grande parte da produção sobretudo nas médias e pequenas cidades.

A re-significação do trabalho artesão tornou-se quase um padrão visual replicado por diferentes desenhistas, litógrafos e fotógrafos dos anos oitocentos e novecentos. Embora não seja objeto desta análise, vale lembrar as litografias de Debret editadas em Viagem pitoresca e histórica ao Brasil na década de 1830 em Paris. ${ }^{37}$ Seu conjunto de imagens tanto nos mostra os ofícios em ateliês, quanto o comércio de seus produtos no Rio de Janeiro até as três primeiras décadas do século XX. Mas, em geral, o dinâmico mercado de carte-de-visite e a indústria dos postais celebraram versões higienizadas do trabalho artesão. Destacaram basicamente os ofícios de rua. Por serem mais visíveis, e em algumas sociedades mais numerosos (temos em mente, sobretudo, os territórios colonizados pelos impérios europeus), é possível que os ofícios de rua tenham atraído mais a atenção dos profissionais da imagem. Não descartamos a hipótese de que os produtores de imagem que no período atuavam nas regiões antes pertencentes aos impérios coloniais estivessem atentos à demanda do mercado visual europeu, na época interessado pelos tipos pitorescos. Tampouco desconhecemos as transformações que então marcavam a Cultura dos Ofícios e a tornavam menos expressiva do que o nascente universo das fábricas. Mas, ainda assim, somos levados a crer em um esquecimento proposital do mundo do artesão, cada vez mais, identificado com o tempo do atraso,

37 DEBRET, J. B. Viagem pitoresca e histórica ao Brasil. São Paulo: Martins Fontes/EDUSP, 1972. (Tradução e notas de Sérgio Milliet, notícia bibliográfica de Rubens Borba de Moraes). 
portanto sem futuro. Convertidos em tipos pitorescos, os ambulantes foram dissolvidos no mercado visual de exotismos urbanos. Perderam, portanto, sua historicidade, seus vínculos com uma cultura secular do trabalho.

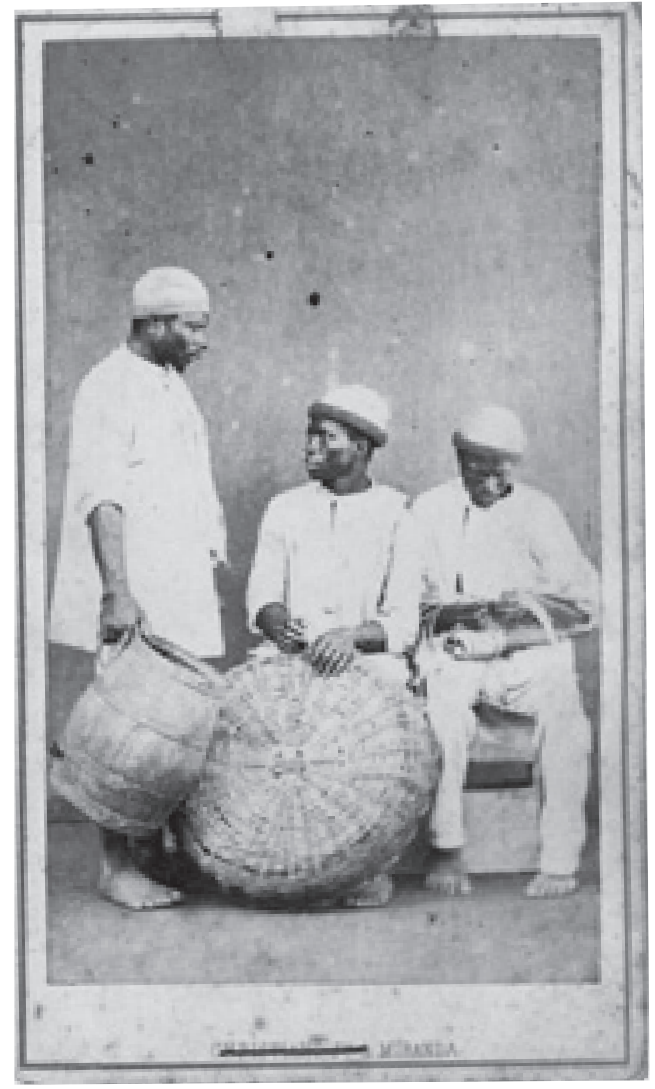

\section{Figura 2}

Fonte: AZEVEDO, Paulo César e LISSOVSKY, Mauricio (orgs). Escravos brasileiros do século XIX na fotografia de Christiano Jr. São Paulo: Ex Libris, 1987.

No caso específico da fotografia, vale lembrar a série de typos de pretos produzida pelo fotógrafo açoriano Christiano Jr, anunciada em 28 de janeiro de 1866 do Almanak Laemmert, na seção de Notabilidades como uma "variada colleção de costumes e typos de pretos, cousa muito própria para quem se retira para a Europa". 38 "Das 77 fotografias da série, 10 poses são de negras de corpo inteiro que ressaltam sua beleza, seus adereços, suas forma de vestir. 40 poses mostram ofícios masculinos e femininos; 07 são de cenas externas; 15 são rostos, masculinos e femininos e 05 apresentam negros de corpo inteiro". As cenas de ofícios perfazem, pois, $51,9 \%$ da representação de 'typos de pretos' que viajariam mundo a fora via

38 AZEVEDO, Paulo César e LISSOVSKY, Mauricio. (orgs.) Escravos brasileiros do século XIX na fotografia de Christiano Jr. São Paulo: Ex Libris, 1987. 
mercado visual. Conforme atestam dois estudiosos da fotografia argentina, "las poses adoptadas por los negros en el estúdio carioca de Christiano Jr. eran similares a las del pescador, el naranjero y los vendedores de diários que retrató pocos años después en su estudio porteño". 39

No estilo da litografia de Dembour e Gancel, esta pose clicada por Christiano Jr nos remete a uma versão higienizada de três negros-de-ganho com seus objetos de trabalho. O negro da direita simula compenetração enquanto maneja fibras vegetais empregadas na feitura de cestas e balaios fartamente usados para transportar diferentes objetos e hortigrangeiros que alimentavam o comércio urbano do período. O resultado do saber dos cesteiros está representado pelo artesão do meio; o terceiro, à esquerda, segura um pequeno tonel, normalmente utilizado para o armazenamento de gêneros alimentícios. ${ }^{40}$ Mais que uma celebração à Cultura dos Ofícios, juntos, eles encarnam uma visão pitoresca do imenso universo dos negrosde-ganho, personagens incontestáveis do comércio de rua do Brasil do período. ${ }^{41}$ Versões semelhantes do viver a rua parecem ter orientado o trabalho de outros fotógrafos, dentro e fora do Brasil.

As três fotografias (Figuras 3, $\mathbf{4}$ e 5) a seguir representam, cada uma a seu turno, uma fração dos acervos de Marc Ferrez sobre os ofícios de rua no Rio de Janeiro entre fins do século XIX e nas duas primeiras décadas do século XX; do italiano Vincenzo Pastore, residente em São Paulo, que manteve, simultaneamente, um estúdio fotográfico na capital paulista e na cidade de Bari/ltália, intitulado: Fotografia Italo-Americana - ai Due Mondi, antes da Primeira Grande Guerra; e do fotógrafo francês, Eugène Atget, que não apenas embalsamou fragmentos do trabalho artesão, como também produziu uma série dedicada aos ofícios de rua no exato momento que as reformas de Haussmann jogavam no esquecimento quarteirões inteiros da Paris do Ancien Régime, espaço por excelência da Cultura dos Ofícios. ${ }^{42}$ Os tocadores de realejo de Atget, os garrafeiros de Ferrez, as vendedoras de hortigranjeiros de Pastore re-apresentam três modalidades de ofícios urbanos que as sociedades desejosas da era industrial e da ideia de progresso nela contida iam jogando no esquecimento.

39 ALEXANDER, Abel e PRIAMO, Luiz. Recordando a Christiano. In: ALEXANDER, Abel, PRIAMO, Luiz e BRAGONI, Beatriz. Un país en transición: fotografias de Buenos Aires, Cuyo y el Noroeste:Christiano Jr., 1867-1883. Buenos Aires: Fundación Antorchas, 2002, p.22.

40 Provavelmente esta pose foi feita em Maceió, onde o fotógrafo teve um estúdio fotográfico: Photographia do Commercio, em sociedade com Fernando Antonio Miranda, no n. 69 da Rua São Pedro. O nome de Christiano $\mathrm{Jr}$, riscado, na base da fotografia, pode significar o rompimento de sua sociedade ocorrido em 1864 .

41 Um estudo mais completo sobre a cultura visual dos chamados "tipos de rua", produzida por brasileiros e estrangeiros no Brasil do período encontra-se em: BORGES, Maria Eliza L. A escravidão em imagens no Brasil oitocentista. In: FURTADO, Júnia F. (org.) Sons, formas, cores e movimentos na modernidade atlântica: Europa, Américas e África. São Paulo: Annablume, 2005, p.333.

42 Para as imagens de Marc Ferrez, ver: VASQUEZ, Pedro Karp. O Brasil na fotografia oitocentista. São Paulo: Metalivros, 2003; e O Brasil de Marc Ferrez. São Paulo: Instituto Moreira Salles, 2005; sobre o ateliê de Vincenzo Patore, ver: Vita Meridonale. I/ Giorno - político, letterario ilustrato del mattino- Mercoledi-Giovedi, Napoli, n.327, Anno XII, p.s., 25-26 novembre, 1914 (a imagem aqui utiliza pertence ao Instituto Moreira Salles); para a produção de Eugène Atget, ver: LE GALL, Guillaume. Atget, Paris pittoresque. Paris: Hazan \& Lumières, 1998. 


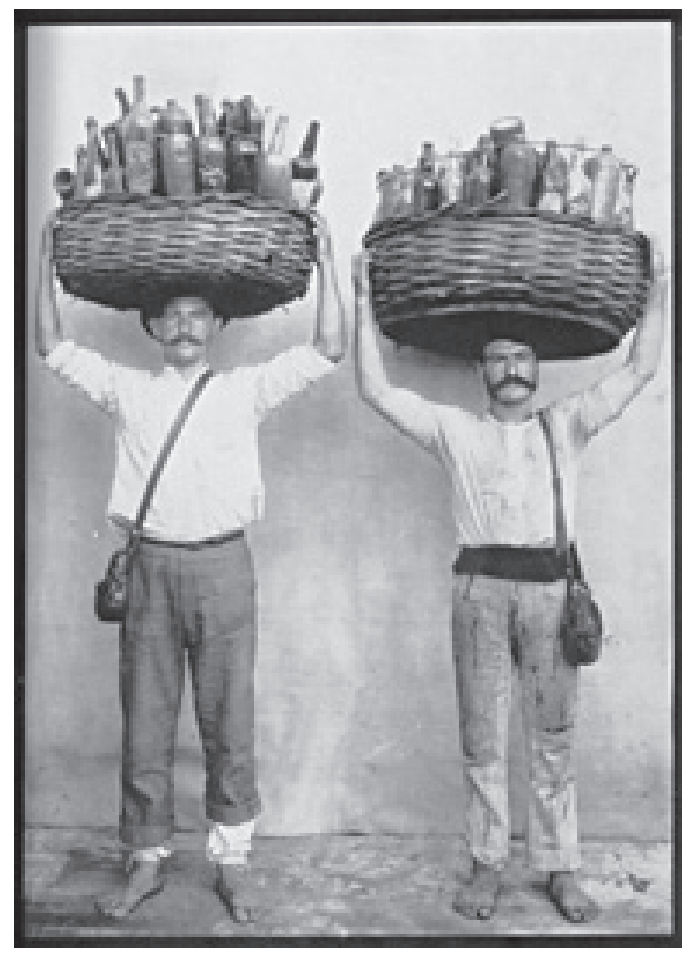

\section{Figura 3}

Fonte: VASQUEZ, Pedro Karp. O Brasil na fotografia oitocentista. São Paulo: Metalivros, 2003.

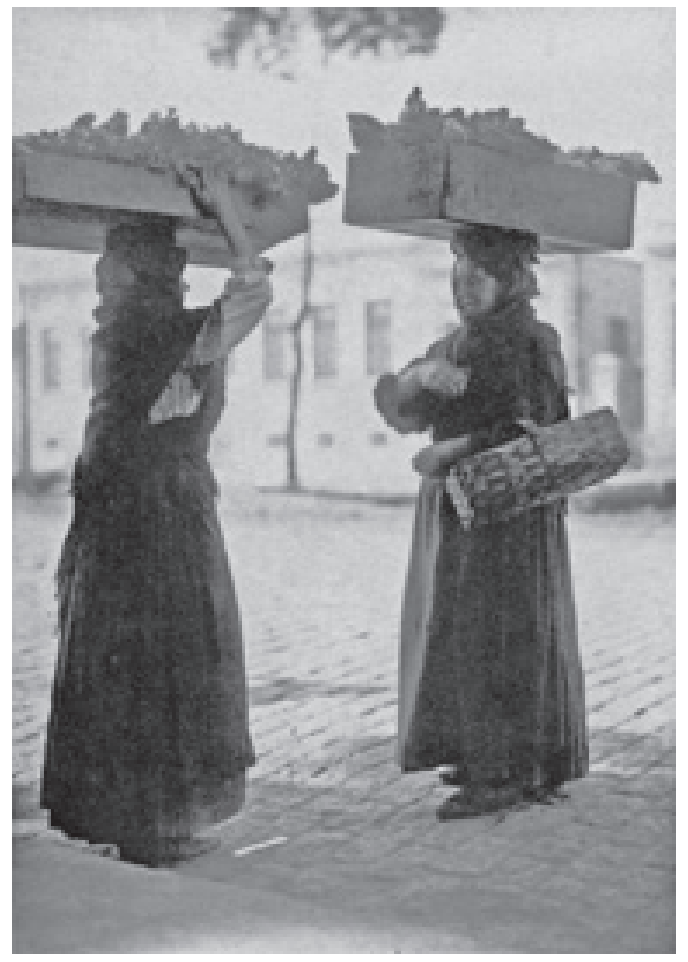

Figura 4

Fonte: Vincenzo Patore, (Instituto Moreira Salles); Eugène Atget, ver: LE GALL, Guillaume. Atget, Paris pittoresque. Paris: Hazan \& Lumières, 1998. 


\section{Figura 5}

Fonte: Eugène Atget, ver: LE GALL, Guillaume. Atget, Paris pittoresque.

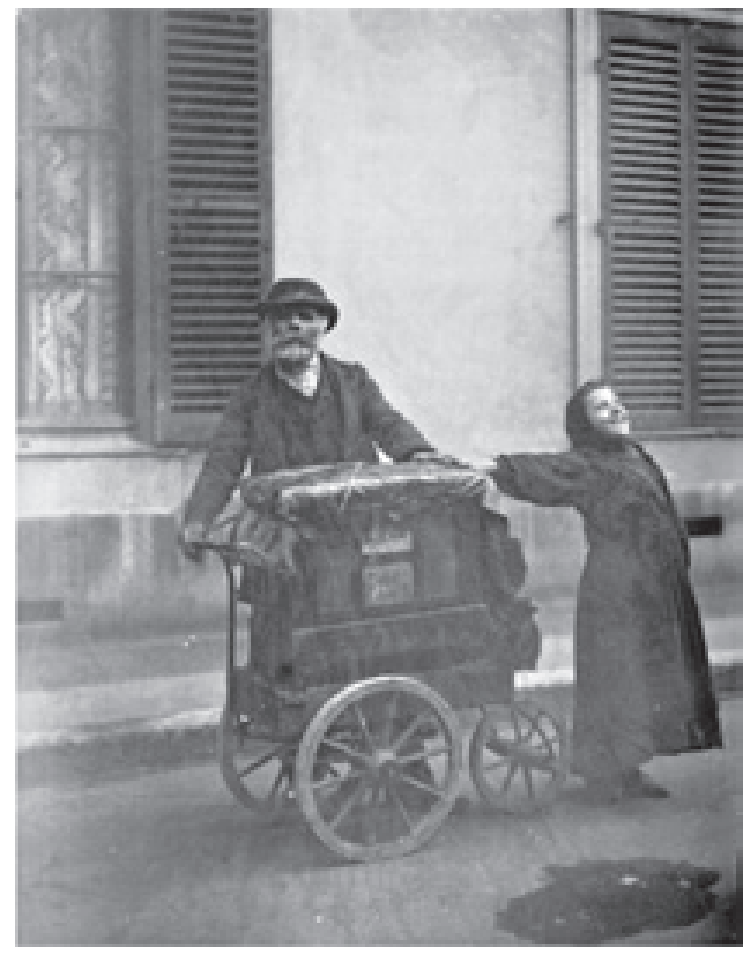

Não raro deparamo-nos com a utilização de imagens produzidas no século XIX e mesmo no século XX para ilustrar objetos produzidos no século XVIII. Será que a linguagem visual dos anos oitocentos e novecentos se propunha a "ilustrar e descrever" modos de produzir e viver dos anos setecentos? Não é demais relembrar: toda gramática visual tem a ver mais com as motivações de seus produtores do que com a realidade propriamente dita. Falam-nos, principalmente, sobre os imaginários sociais dos atores que as produziram e do público que em geral as consumiam. Mesmo sabendo que a terminologia da Cultura Operária da primeira metade do século XIX atesta a influência da Cultura dos Ofícios no mundo do trabalho e das relações sócio-culturais que marcaram o viver operário, não podemos desconhecer: as tradições dessa cultura foram fortemente alteradas a partir da era industrial. Portanto, encarar tais imagens como documento da Cultura dos Ofícios, strictu senso, é um ato de anacronismo.

Na realidade, a cultura visual do século XIX, sobretudo a fotográfica, pouco nos diz acerca das "condições históricas" dos atores nelas representados. São, antes de mais nada, a expressão da produção, da circulação e da reprodução de imaginários sociais, muitos deles idealizados, porque saudosistas, da Cultura dos Ofícios.

Reproduzidas de forma descontextualizadas em diversos museus hoje dedicados à memória da Cultura dos Ofícios, imagens como essas acabam 
por reforçar uma visão descarnada, quase a-histórica, de um mundo longevo e universal, feito à mão e marcado por redes de sociabilidades face to face. Assim apresentadas, elas pouco têm a dizer sobre a trajetória história de mestres, artífices e aprendizes. Para que sejam realmente trabalhadas como objetos museais e patrimoniais de suas respectivas sociedades, é preciso que essas e outras imagens similares sejam problematizadas à luz dos estudos históricos e mais especificamente das análises sobre as intenções dos produtores visuais do período que as produziu; caso contrário, elas reforçarão memórias e/ou interpretações saudosistas. Em suma, pouco dirão sobre o chão de tensões e conflitos (internos e externos) que as ancorou.

Em 2009, o Instituto Cultural Banco Real e a Fundação Pierre Verger, realizaram uma exposição temporária sobre a obra de Mestre Vitalino e de Pierre Verger. Um de seus produtos foi a edição de um álbum com uma série de dez fotografias narrando os passos do processo de produção de uma das esculturas de Mestre Vitalino. Para além da beleza plástica desse trabaIho, a sequência das imagens, devidamente contextualizadas, demonstra o comprometimento histórico dos realizadores da exposição com a memória patrimonial. ${ }^{43}$ Trabalhos como este denotam o cuidado, a sensibilidade histórica, com cada temporalidade dos modos de produzir artesanais. Antes: são representações que não apenas dialogam com a Cultura dos Ofícios, mas também se preocupam em destacar as especificidades de seus ecos na era industrial. Enfim, criam condições para que a memória criada pela cultura visual dos anos oitocentos e novecentos transcenda o pitoresco e contribua para a educação patrimonial e museal.

\section{Considerações Finais}

Enquanto os museus de artes e ofícios e a cultura visual do passado contribuíram para jogar no esquecimento o viver dos ateliês, os governos e algumas ordens religiosas, como a dos salesianos, por exemplo, fizeram das escolas de artes e ofícios (criadas ao longo do século XIX e nas primeiras décadas do século seguinte) um lugar para a educação de órfãos pobres e filhos de trabalhadores. Simultaneamente, os memorialistas urbanos, testemunhos do avanço da urbanização que bania os antigos ofícios de seus cenários, teciam narrativas nostálgicas, idealizadas, sobre o tempo da Cultura dos Ofícios. Não raro, ainda hoje nos deparamos com pessoas que reproduzem tais comportamentos.

Para os que trabalham com políticas patrimoniais, especialmente com programas que lançam mão de relatos orais, de histórias de vida, como é o caso do Inventário Nacional de Referências Culturais que alimenta o Livro de registro dos saberes, o Livro das celebrações, o Livro das formas de

43 LODY, Raul. (curador) Arte do Barro e o olhar da arte/ Vitalino e Verger. Recife: Instituto Cultural Banco Real, 2009. 
expressão e o Livro dos lugares, vale lembrar: é comum nos depararmos com relatos orais onde os próprios narradores mitificam suas histórias profissionais iniciadas nas escolas de artes e ofícios da primeira metade do século XX ou mesmo na prática de seus ofícios. Involuntariamente ou não, seus relatos tendem a omitir fatos que evidenciam a domesticação de seus corpos, as tensões vivenciadas no ambiente de trabalho, a ausência de direitos e o desprestígio social que pautou seu cotidiano profissional. Fatos como esses são perfeitamente compreensíveis, afinal as narrativas orais são, na maioria das vezes, a única oportunidade que o entrevistado tem para publicizar sua trajetória de vida. Por isso, ele prefere lembrar e destacar suas conquistas pessoais, o processo de mobilidade social de sua família, sempre conectado ao fruto de seu trabalho e, simultaneamente, jogar no esquecimento as marcas de sua vida profissional ligadas à disciplinarização de seu corpo ou aos sofrimentos psíquicos que ele crê manchar uma história construída com orgulho e trabalho. A título de exemplo, relembro aqui uma entrevista, realizada com um alfaiate de Belo Horizonte, em que o narrador só mostrou-me as varizes de sua perna, fruto do uso ininterrupto de uma máquina de costura manual, após se certificar de que eu tinha desligado o gravador. Indagado sobre o porquê de seu silêncio durante a gravação da entrevista, ele me disse: "eu não quero que os outros pensem que minha profissão foi um fardo". ${ }^{44}$ Assim como as representações visuais, aqui apresentadas, ou mesmo como as obras dos memorialistas urbanos, omissões como esta tendem a produzir leituras estereotipadas, pitorescas, sobre o trabalho e os modos de vida dos herdeiros da Cultura dos Ofícios no século XX. Por essas e outras razões, a participação respeitosa - mas sempre ativa do pesquisador - no processo de construção de histórias de vida ou de histórias temáticas, narradas a partir do método da história oral, pode ser um antídoto contra a produção de memórias que criam verdadeiras "ilusões biográficas", para usarmos uma expressão cara à Pierre Bourdieu, ${ }^{45}$ e dificultam compreensão da história dos atores em questão.

Os trechos a seguir contêm fragmentos de um trabalho que desenvolvemos entre 2005 e 2008 na pesquisa intitulada: Pequenos Ofícios na Memória e na História - Belo Horizonte 1920-1960, realizada no então Programa de Historia Oral da FAFICH/UFMG, hoje Núcleo de História Oral/ FAFICH/UFMG. Transcritas, indexadas e disponíveis à consulta pública, as entrevistas realizadas com fotógrafos ambulantes, linotipistas, barbeiros e alfaiates conformam um valioso acervo que, dentre outros aspectos, guarda traços do ethos da Cultura dos Ofícios. Para estimular o interesse de pos-

44 Como esta informação nos foi dada após desligarmos o gravador, mantemos um dos princípios da história oral que nos orienta a revelar apenas o que o entrevistado nos autoriza.

45 BOURDIEU, Pierre. A ilusão biográfica. In: FERREIRA, Marieta de M. e AMADO, Janaina. Usos \& abusos da historia oral. $3^{\text {a }}$ ed. Rio de Janeiro: FGV, 2000, p.183-192. 
síveis pesquisadores, encerramos este artigo dando voz ao Sr. Waldemar Boggione, que em oito de julho de 2006 narrou-nos suas memórias de contra-mestre de alfaiate.

Nascido em Belo Horizonte em 1920, Waldemar Boggione descende de uma família de imigrantes italianos. Órfão de mãe aos oito anos de idade, iniciou sua trajetória de aprendiz de alfaiate aos quinze anos. Após trabalhar como aprendiz em dois ateliês de alfaiataria da capital mineira, passou vinte e cinco anos como contra-mestre em uma terceira alfaiataria. Quando esta fechou suas portas, ele permaneceu no ofício por mais vinte e cinco anos em sua residência.

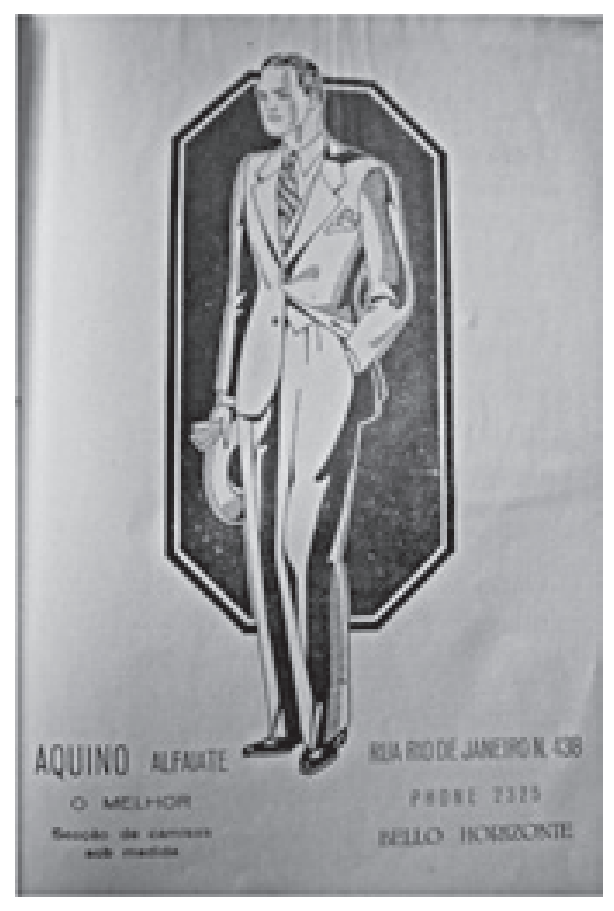

\section{Figura 6}

Fonte: Anúncio da alfaiataria Mendes, arquivo da autora.

\section{Trajetória de artesão}

Vejamos alguns trechos da entrevista com Waldemar Boggione:

Naquela ocasião [meados dos anos de 1930], o aprendiz não tinha remuneração nem para a condução (...). Naquela ocasião tinha aqui uma grande alfaiataria que era do Mendes. Muitos oficiais da alfaiataria do Aquino [onde ele trabalhara antes] foram trabalhar lá no Mendes.

Um ajudante de contra-mestre, que mais tarde também teve alfaiataria, que era o Josias, veio morar perto da minha casa. Eu, a noite ia ajudando o Josias. Ele aí viu que eu sabia trabalhar, (...) e falou com..., com o contra-mestre que trabalhava lá (...), o Carvalho. Ele veio do Rio de Janeiro pra cá. E ai eu fui trabalhar lá. [A alfaiataria] tinha o nome do proprietário: 'Mendes Alfaiate'. 
O Mendes gostava muito do meu trabalho. Ficou gostando muito do meu trabalho que era até... referência para os outros. Depois eu trabalhei com o Simas; quando sai de lá eu vim trabalhar em casa. Porque o Simas adoeceu, acabou morrendo. Não é? Eu vim trabalhar em casa. Aqui em casa eu trabalhei também, mais ou menos, uns vinte anos...

Figura 7

Fonte: Dedal de alfaiate, arquivo da autora.

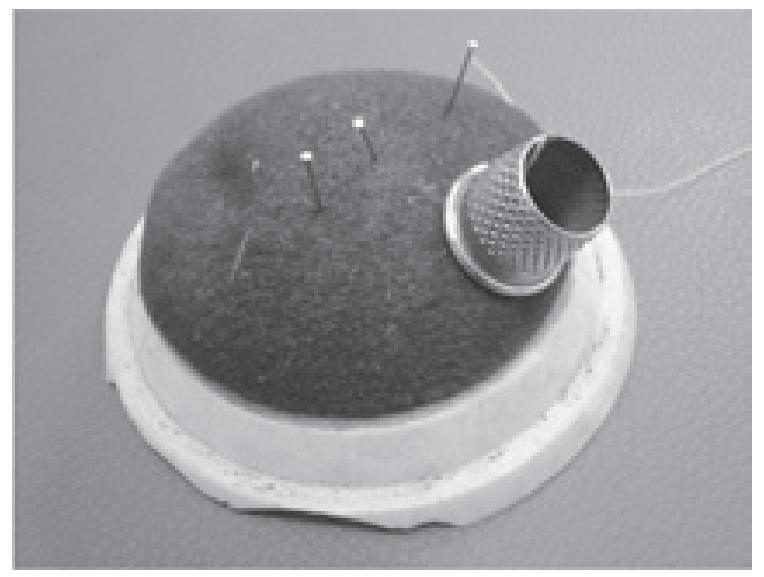

\section{Domesticação do corpo, instrumentos de trabalho, materiais, saber e modos de produzir}

Antigamente a roupa era toda artesanal. Não é como hoje. Não é? Hoje não tem mais oficiais. Só tem operário... Uma pessoa faz uma peça, outro faz outra, outra faz outra... É, e aí no fim um vai juntando aquilo e aquilo é feito rapidamente. Não é? (...) lá não, eu trabalhava com ferro a carvão. E era um ferro muito grande. Não é? E ali a gente tinha que tá mantendo aquele carvão sempre para o ferro estar quente, não é? E a máquina que a gente usava era essas máquinas antigas. À pedal, a gente não tinha nem motor. Mais tarde é que começou a surgir motor e que começou então surgir os ferros... é ferro elétrico não é? (...) E aquele trabalho era todo assim, feito manual. Hoje [se faz] de tudo... Eh!... quase não se usa agulha como a gente.

Porque antigamente a gente usava umas agulhas muito pequenas, não é? E quando começava na profissão, a gente tinha primeiramente que amarrar o dedo pra acostumar o dedo ficar torto. Porque o dedal de alfaiate não tem um fundo. Ele [o oficial] amarrava no aprendiz, ali, para que o dedo acostumasse a ficar torto, para poder trabalhar, que a gente trabalhava de lado. A costureira trabalha com a ponta do dedo. Nós não.

É diferente do modo de pegar... também a tesoura, esquadro e o pau de gola Tinha, tinha giz azul, tinha giz amarelo, tinha... giz branco. Ali a gente até giz preto também tinha. Tanto eu tirava medidas, como provava, como cortava, e fazia. Não tinha horário, meu horário era de, de acordo com as necessidades...

O que os fregueses encomendavam pra gente era feito, não é? Na época tinha alfaiatarias com vinte e cinco oficiais né? Na ocasião, a primeira vez que o cliente chegava a gente tirava a medida. Tirava-se a medida; depois, então, tinha mais duas provas. Saber provar uma roupa é muito difícil. As minhas provas ele [o dono da alfaiataria] mostrava. Era referência [porque] eu tinha muito capricho. 


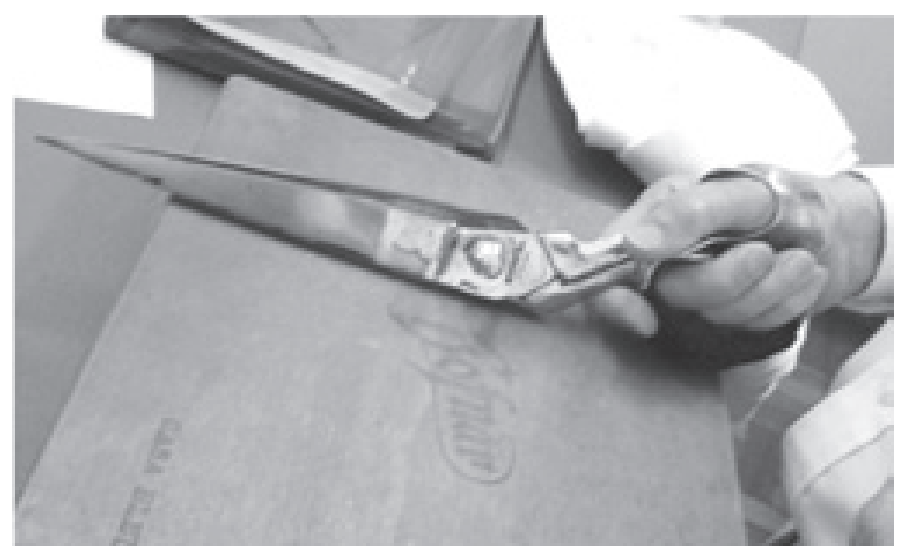

\section{Figura 8}

Fonte: Tesoura de alfaiate, arquivo da autora.

Como os antigos diziam: - "Corte quem quiser, e prove quem souber".

Algumas [alfaiatarias] tinham tecidos. Outras não. Por exemplo, o Mendes tinha muito tecido, o Aquino tinha muito tecido. E o Simas também passou a ter muito tecido. Ah, a senhora vê que eles falam na caxemira, né? ${ }^{46}$ Pois é, a... aquilo, a melhor roupa chamava [Silver Kid] era feito dessas cabras lá da Caxemira. Era fabricada na Inglaterra. A... é.... pessoa... chamava [Silver Kid] não é? Esse [tecido] dá um caimento muito bom. Então o [Silver Kid] era feito dessa fibra, dessas cabras. É quase igual o linho, porque o linho é..., a natureza dele é fresquinha, não é? O linho também era muito bom. A gente fazia com o S-120 que é o melhor linho, não é? Ele vem da Holanda...

$\mathrm{Na}$ ocasião apareceu um, um camarada que fabricava tesouras, niquelava direitinho, bonitinho. E chegou lá pra me vender, é... me oferecendo a tesoura. Eu, quando peguei a tesoura dele... Quando eu olhei ela assim, falei:-Ah, essa tesoura não me serve (...); você espera aí. Eu vou buscar aqui a [tesoura] profissional. (...) Eh! ele não sabia desse, desse segredo" [ao mencionar o "segredo", nosso entrevistado se referia à especificidade da tesoura do alfaiate naquele período]. ${ }^{47}$

Mesmo não silenciando sobre "as dores" de seu ofício, esta e outras entrevistas de oficiais dão sinais da distância da postura política dos oficiais (mestres, contra-mestres e aprendizes) das lutas dos movimento operário da época. Outro dado importante desse conjunto de entrevistas com herdeiros da Cultura dos Ofícios é fato delas conterem informações significativas sobre a natureza da rede de sociabilidades que caracterizaram o cotidiano desses atores na Belo Horizonte nas primeiras décadas do século XX. Aliados à pesquisa documental, textual e visual, esses dados são cruciais para a construção da memória histórica dos ofícios no momento em que sua cultura ia sendo substituída pela Cultura Operária.

46 Ele se refere à casimira.

47 Entrevista realizada com Waldemar Boggione. Belo Horizonte, 08/06/2006. Entrevistadores: Maria Eliza Linhares Borges (pesquisadora), Lucas Carvalho, Soares de A. Pereira e Anelise S. Coelho (bolsistas). Programa de História Oral - Centro de Estudos Mineiros - Faculdade de Filosofia e Ciências Humanas - Universidade Federal de Minas Gerais. Esta e outras entrevistas na íntegra podem ser consultadas no site: www.fafich.ufmg.br/historioral. 